\title{
Konstruksi Jilbab sebagai Simbol Keislaman
}

\author{
Dadi Ahmadi dan Nova Yohana
}

\begin{abstract}
Veil usage is not only just a matter of fashion style. Moreover, veils symbolize many great values in Islamic tradition. No wonder if veil-or jilbab - are commonly found in many places, including campus, among students as well as lecturer. This research aimed to investigate the motivation of the girls in wearing jilbab. Using phenomenology approach to know more about subjectivity meanings constructed between research subjects, the research has finally revealed some motivations among the girls in wearing jilbab. There are three motives in wearing jilbab as found among Unisba's students: theological motive, psychological motive, and fashionable motive. Such motive further implied on three different identities constructed by research subjects: Phenomenal Moslem Students, Fashionable Moslem Students, and Tolerant Moslem Students.
\end{abstract}

Kata kunci: jilbab, fenomenologi, motivasi, mahasiswi

\section{Pendahuluan}

Dasawarsa ini, sungguh eksentrik geliat religius yang menjangkit bangsa kita, di mana pemakai jilbab terus bertambah, utamanya di kalangan mahasiswa dan pelajar. Perjalanan panjang pemakaian jilbab di Indonesia memang tergolong keras dan berliku. Namun, akhirnya setelah melalui tarik ulur yang cukup lama, tahun 1991 pemerintah mengeluarkan SK No. 100 yang intinya membolehkan penggunaan jilbab di setiap lembaga pendidikan (Jamil, 2002: 11). Sejak saat itu, laju pemakaian jilbab hampir tak dapat dibendung lagi. Dampak dari SK 1991 ini, para pelajar semakin mudah menggunakan jilbab. Tak hanya di sekolah ataupun universitas, jilbab bahkan sudah menyentuh ibu rumah tangga, para pegawai kantor, bahkan para artis. Adanya beberapa artis yang konsisten memakai jilbab yang menurut para desainer, lebih terlihat aura kecantikannya setelah memakai jilbab turut mempengaruhi masyarakat dalam berpakaian.

Dalam beberapa tahun terakhir, jilbab telah menjadi trend, yang turut menumbuhkan sektorsektor baru dalam bidang ekonomi. Namun, trend ini bukannya tanpa konflik. Beberapa tahun terakhir, setidaknya tampak dua kelompok pemakai jilbab. Kelompok pertama mewakili gerakangerakan yang berambisi untuk kembali ke Islam. Menurut Rais, gerakan yang meluas di kampuskampus dunia Islam memengaruhi proses jilbalisasi, yang secara simbolik, dapat ditafsirkan sebagai usaha identifikasi diri di tengah krisis identitas yang melanda kaum muda (Rais,1991:95). Muslimah kelompok ini dapat dikenali dari jilbab lebar yang khas, gamis, longdress yang lebar atau 
rok, dan baju atasan yang juga serba lebar, juga kaki yang selalu tertutup dengan kaos kaki. Potret jilbab lebar sering diidentikkan dengan simbol kesalehan dan kesopanan, fundamentalis, konservatif, militan, antimodernisasi, dan sebagainya.

Kelompok kedua , merupakan anti thesis dari kelompok pertama. Mereka mewakili simbol kebebasan, modernis, cara berpakaian mereka juga dapat dikenal, jilbab kecil yang dililitkan ke leher, baju dan celana super ketat, yang mempertegas lekuk tubuh. Jilbab seperti ini adalah bentuk ekspresi kawula muda yang menuntut kebebasan berpakaian. Sebagai seorang muslimah, mereka tidak mau menanggalkan jilbabnya, tapi juga tidak mau ketinggalan zaman, atau disebut kampungan (al-Ghifari, 2004 : 1-2).

Konsep jilbab didasarkan pada kewajiban agama Islam bagi pemeluknya untuk menutup aurat dengan jilbab terutama kaum muslimah. Salah satu dasar hukum jilbab adalah QS An Nuur 31. Berikut kutipan QS An Nuur 31 tersebut:

Katakanlah kepada wanita yang beriman: "Hendaklah mereka menahan pandangannya, dan kemaluannya, dan janganlah mereka menampakkan perhiasannya, kecuali yang (biasa) tampak dari padanya. Dan hendaklah mereka menutupkan kain kudung ke dadanya, dan janganlah menampakkan perhiasannya kecuali kepada suami mereka, atau ayah mereka, atau ayah suami mereka, atau puteraputera mereka, atau putera-putera suami mereka, atau Saudara-saudara laki-laki mereka, atau puteraputera saudara lelaki mereka, atau putera-putera saudara perempuan mereka, atau wanita-wanita Islam, atau budak-budak yang mereka miliki, atau pelayan-pelayan laki-laki yang tidak mempunyai keinginan (terhadap wanita) atau anak-anak yang belum mengerti tentang aurat wanita. Dan janganlah mereka memukulkan kakinya agar diketahui perhiasan yang mereka sembunyikan. Dan bertaubatlah kamu sekalian kepada Allah, hai orang-orang yang beriman supaya kamu beruntung."

Aurat perempuan, menurut Islam, adalah seluruh tubuh, kecuali muka dan telapak tangan. Aurat tidak boleh diperlihatkan kecuali terhadap suami atau mahramnya (saudara atau kerabat dengan kriteria tertentu), yang implikasinya secara umum mewajibkan perempuan menutup auratnya terutama bila di luar ataupun ke luar rumah. Pada prakteknya, tidak semua perempuan muslim mempunyai pemahaman dan kesadaran yang sama mengenai konsep tersebut walaupun wejangan agama dalam berbagai kajian keislaman seringkali menyinggung hal ini.

Tradisi berjilbab merupakan fenomena yang kaya makna dan penuh nuansa, meminjam istilah Geertz (Geertz,1992), telah menjadi semacam keyakinan dan pegangan hidup. Ia dianggap merupakan bagian dari great tradition yang ada dalam Islam. Namun, lebih dari itu, jilbab juga berfungsi sebagai bahasa yang menyampaikan pesan-pesan sosial dan budaya. Tradisi berjilbab pada awal kemunculannya sebenarnya merupakan penegasan dan pembentukan identitas keberagamaan seseorang. Dalam perkembangannya, pemaknaan jilbab tersebut ternyata mengalami pergeseran makna yang signifikan. Jilbab tidak hanya berfungsi sebagai simbol identitas religius, tetapi telah memasuki ranah-ranah budaya, sosial, politik, ekonomi, dan bahkan fesyen. Dengan kata lain, jilbab telah menjadi sebuah fenomena yang kompleks. Ia tidak hanya menjadi identitas keberagamaan, tetapi juga menjadi identitas kultural. Dalam konteks ini, jilbab menjadi medan interpretasi yang penuh makna. Gejala semacam ini dengan mudah dapat dijumpai dalam kehidupan sosial.

Pergeseran makna berjilbab ke bentuk identitas yang plural tampaknya bukanlah sesuatu yang berdiri begitu saja. Ada kekuatan besar yang juga sangat menentukan, yakni globalisasi. Globalisasi dengan berbagai kekuatan yang ada di dalamnya, ternyata mampu menjadikan jilbab yang semula hanya identitas keberagamaan menjadi multiidentitas.

Di hampir semua kampus di Indonesia, baik yang berlabelkan Islam maupun umum, akan dijumpai mahasiswi yang memakai jilbab dengan segala macam bentuknya. Tak terkecuali Universitas Islam Bandung (Unisba) yang menjadi tempat penelitian. Unisba lahir atas gagasan para tokoh umat Islam dan tuntutan masyarakat Jawa Barat akan adanya perguruan tinggi yang bernafaskan 
Islam dan melahirkan intelektual muslim. Penelitian ini sangat menarik karena mengingat Universitas Islam Bandung sebagai salah satu lembaga pendidikan yang berlabelkan Islam di tengah Kota Bandung. Dapat dipastikan, peserta didiknya tidak asing lagi dengan isu-isu di atas, terlebih mayoritas mahasiswa Universitas Islam Bandung beragama Islam.

\section{Fokus Penelitian}

Menyoal jilbab, tampaknya seperti mencari jalan tak berujung, karena fenomena jilbab selalu muncul dengan berbagai ekspresi dan pesan di belakangnya. Melihat berbagai kondisi di atas, maka masalah fokus penelitian ini adalah "Bagaimana konstruksi realitas jilbab sebagai simbol keislaman terkait dengan motivasi mahasiswi Universitas Islam Bandung memakai jilbab dan perilaku mahasiswi berjilbab sebagai manifestasi identitas diri seorang muslimah."

\section{Pendekatan}

Jilbab adalah busana muslimah, yaitu suatu pakaian yang tidak ketat atau longgar dengan ukuran yang lebih besar yang menutup tubuh perempuan, kecuali muka dan telapak tangan sampai pergelangan (Surtiretna, 2003:52-54).

Secara etimologis, kata jilbab berasal dan bahasa Arab, dan bentuk jamaknya tercantum dalam al-Qur'an surat A1-Ahzab (33) ayat 59 yang artinya:

"Hai Nabi, katakanlah kepada istri-istrimu, anakanak perempuanmu, dan istri-istri orang mukmin, hendaklah mereka mengulurkan jilbab mereka ke seluruh tubuh mereka. Yang demikian itu supaya mereka lebih mudah untuk dikenal, karena itu mereka tidak diganggu. Dan Allah adalah Maha Pengampun lagi Maha Penyayang."

Persoalan pemakaian jilbab tidak dapat dipisahkan dari persoalan aurat, yakni batas minimal bagian tubuh yang wajib ditutup, karena perintah Allah SWT Surat al-Ahzab (33) ayat 59 di atas merupakan ayat yang memerintahkan kepada kaum wanita muslimah untuk menutup tubuh mereka, karena tubuh wanita itu adalah aurat.

Jilbab adalah bagian dari pakaian muslimah.
Pakaian, selain berfungsi untuk menutup aurat, memiliki banyak alasan lainnya, hal ini lebih jelasnya adalah sebagaimana digambarkan sebagai berikut:

Pakaian tertentu berhubungan dengan perilaku tertentu. Umumnya pakaian kita pergunakan untuk menyampaikan identitas kita, untuk mengungkapkan kepada orang lain siapa kita. Menyampaikan identitas berarti menunjukkan kepada orang lain sepatutnya memperlakukan kita. Selain itu pakaian digunakan untuk menyampaikan perasaan (seperti blus hitam ketika wanita berduka cita, atau pakaian semarak ketika ceria), status dan peranan (seperti seragam pegawai kantor), dan formalitas (seperti memakai sandal untuk menunjukkan situasi formal dan memakai batik untuk situasi formal). (Rakhmat, 1999:292)

Penampilan fisik seseorang dipengaruhi oleh nilai-nilai agama, kebiasaan, lingkungan, kenyamanan, dan tujuan pencitraan. Seperti dalam mengenakan pakaian, banyak orang yang berbusana khas sebagai simbol sebuah kelompok. Seorang muslimah memakai jilbab sebagai manifestasi ajaran Islam. Pemakaian jilbab merupakan salah satu pesan artifaktual.

Simbol adalah sesuatu yang perlu dipelajari, ditangkap, dan ditafsirkan maknanya. Bila kita mengamati keadaan di sekeliling kita, maka kita akan menemukan bahwa hidup kita sehari-hari sebenarnya dilingkupi dengan beraneka macam simbol. Manusia hampir tidak mungkin hidup tanpa simbol. Sepanjang hidup, manusia berkecimpung dalam simbol dan tanda, simbol merupakan bagian integral dari hidup manusia. Tidak dapat dibayangkan manusia hidup tanpa simbol. Simbol adalah sesuatu yang digunakan untuk menunjuk suatu yang lainnya berdasarkan kesepakatan sekelompok orang (Mulyana, 2000: 84).

Lambang atau simbol yang ditimbulkan oleh manusia dapat dibedakan atas simbol yang bersifat verbal dan nonverbal (Pateda, 2001:48). Simbol verbal adalah simbol-simbol yang digunakan sebagai alat komunikasi yang dihasilkan oleh alat bicara, sedang simbol nonverbal dapat berupa (1) simbol yang menggunakan anggota badan, (2) suara, (3) simbol atau tanda yang diciptakan oleh manusia untuk menandai waktu, (4) benda-benda 
yang bermakna kultural dan ritual (Sobur, 2003:122). Suatu konsep makna bisa ditunjukkan dengan simbol (cincin merupakan simbol perkawinan, bendera merupakan simbol bangsa, dsb). (Liliweri, 1994:5). Begitu pula jilbab merupakan simbol agama Islam. Berkaitan dengan hal itu, Clifford Geertz (1992 : 5) mendefinisikan agama sebagai :

(1) Sebuah sistem simbol yang bertujuan untuk (2) menciptakan perasaan dan motivasi kuat, mudah menyebar, dan tidak mudah hilang dalam diri seseorang (3) dengan cara membentuk konsepsi tentang sebuah tatanan umum eksistensi dan (4) melekatkan konsepsi ini kepada pancaran-pancaran faktual, dan pada akhirnya perasaan dan motivasi ini akan terlihat sebagai suatu realitas yang unik.

Geertz kemudian menyimpulkannya, bahwa agama menyebabkan seseorang merasakan atau melakukan sesuatu. Dalam hal ini, seseorang memperlihatkan simbol-simbol keagamaan dalam perilakunya akibat dari motivasi tertentu yang muncul dalam dirinya. Motivasi ini tentunya mempunyai tujuan-tujuan tertentu dan orang yang termotivasi tersebut akan dibimbing oleh seperangkat nilai tentang apa yang penting, apa yang baik dan buruk, apa yang benar dan salah bagi dirinya.

Motif adalah keadaan dalam pribadi orang yang mendorong individu untuk melakukan aktivitas-aktivitas tertentu guna mencapai suatu tujuan (Suryabrata, 1993:70). Jadi, motif bukanlah hal yang dapat diamati, tetapi dapat disimpulkan adanya karena sesuatu kekuatan dari dalam diri orang itu. Kekuatan pendorong inilah yang kita sebut motif.

Menurut Sartain (dalam Purwanto 1985 : 64), motif adalah suatu pernyataan yang kompleks di dalam suatu organisme yang mengarahkan tingkah laku/perbuatan ke suatu tujuan atau perangsang. Tujuan (goal) adalah yang menentukan atau membatasi tingkah laku organisme itu. Jika yang kita tekankan ialah faktanya atau objeknya, yang menarik organisme itu, maka kita pergunakan istilah "perangsang” (incentive).

Motif itu merupakan suatu pengertian yang melingkupi semua penggerak, alasan-alasan atau dorongan-dorongan dalam diri manusia yang menyebabkan ia berbuat sesuatu. Motif manusia merupakan dorongan, keinginan, hasrat dan tenaga penggerak lainnya yang berasal dari dalam dirinya, untuk melakukan sesuatu (Gerungan, 1996:140).

Motivasi mahasiswi memakai jilbab dengan pilihan gaya jilbab di sini merupakan kesadaran diri dari pemahaman seseorang tentang konsep jilbab sebagai pakaian muslimah yang menutup aurat. Gagasan tentang "kesadaran" (consciousness) subjek yang sedang diteliti merupakan istilah kunci karena hal itu merupakan esensi diri.

Bagi Mead (dalam Mulyana, 2001:76), kesadaran diri berarti menjadi suatu diri dalam pengalaman seseorang sejauh

"suatu sikap yang dimilikinya sendiri membangkitkan sikap serupa dalam upaya sosial.... Kita tampil sebagai diri dalam perilaku kita sejauh kita sendiri mengambil sikap yang diambil orang lain terhadap kita. Kesadaran diri muncul ketika "individu memasuki pengalaman dirinya sendiri sebagai suatu objek."

Senada dengan itu, menurut Musgrove (Mulyana, 2001 : 76), kesadaran adalah koneksi antara diri yang mengamati, mengetahui dan berefleksi dan lingkungan sosial. "Kesadaran adalah pemahaman manusia atas pengalamannya sendiri dan keadaanya." Dengan kata lain, kesadaran-diri menurut Mead menyangkut objektivitas diri.

Dalam ilmu komunikasi, perilaku (behavior) merupakan konsep yang cukup penting. Sebagaimana kita pahami bahwa setiap aktivitas komunikasi akan mempunyai efek terhadap perilaku. Perilaku manusia adalah suatu fungsi dari adanya interaksi antara individu dengan lingkungannya (Thoha, 1998:29). Sementara itu, Chaplin (1993:53) mendefinisikan perilaku sebagai sebuah konsep yang luas, yakni:

"segala sesuatu yang dilakukan atau dialami seseorang, sedang dalam pengertian yang lebih sempit, perilaku dapat dirumuskan hanya mencakup reaksi yang dapat diamati secara umum atau obyektif."

Dalam penelitian ini, konsep perilaku yang digunakan adalah perilaku beragama dalam Islam yang menyandarkan diri pada tata nilai Islam, yakni 
Al-Qur'an dan Hadist. Dalam al-Qur,an standar perilaku yang baik adalah segala perbuatan yang tidak melanggar aturan Allah.

Jika ditelusuri, munculnya perilaku dengan menggunakan simbol-simbol keagamaan ini, tidak lepas dari konteks dan tujuan yang ingin dicapai masing-masing individu atau pelaku simbol. Geertz (dalam Sobur, 2003 ; 177) menelusuri bahwa simbolsimbol keagamaan yang melekat pada seseorang itu memainkan suatu bagian yang penting dalam praktek keagamaan, yang selanjutnya memperkuat keyakinan yang diakui bersama. Bahkan Geertz mengatakan agama memiliki sebuah kekuatan dalam menyangga nilai-nilai sosial, di mana kekuatan itu terletak pada kemampuan simbolsimbolnya untuk merumuskan sebuah dunia tempat nilai-nilai itu berada. Agama melukiskan kekuatan imajinasi manusia untuk membangun sebuah gambaran kenyataan melalui simbolsimbolnya.

\section{Kerangka Pemikiran}

Penelitian ini berusaha untuk menkonstruksi realitas jilbab sebagai simbol keislaman terkait dengan apa motivasi mahasiswi berjilbab di Universitas Islam Bandung, dengan gaya jilbab yang dipilihnya melalui perspektif fenomenologis, yakni menganggap kesadaran manusia dan makna subjektivitasntya sebagai fokus untuk memahami tindakan sosial.

Pada dasarnya, seperti dikatakan Rakhmat (1999), kaum fenomenologis berusaha memasuki dunia konseptual subjek, untuk mengetahui bagaimana orang mengonstruksi makna terhadap peristiwa-peristiwa kehidupan mereka. Berger dan Luckmann (1967), sebagaimana dikutip Rakhmat (1999), menyatakan bahwa fenomenologi yakin bahwa realitas adalah socially constructed.

Schutz(dalam Cresswell, 1998:53) menjelaskan bahwa fenomenologi mengkaji bagaimana anggota masyarakat menggambarkan dunia sehari-harinya, terutama bagaimana individu dengan kesadarannya membangun makna dari hasil interaksi dengan individu lainnya. Analisis fenomenologi dapat mengonstruksi dunia kehidupan manusia, yakni bentuk yang mereka alami sendiri.

Sementara itu, Natanson (dalam Mulyana, 2001:59), mendefinisikan istilah fenomenologi sebagai suatu istilah generik untuk merujuk pada semua pandangan ilmu sosial yang menganggap kesadaran manusia dan makna subjektifitasnya sebagai fokus untuk memahami tindakan sosial.

Morgan dan Smircih (Mulyana, 2001:48) menjelaskan bahwa realitas fenomenologis merupakan proses manusia yang menilai dan menafsirkan fenomena dalam kesadaran sebelum memahami strukur makna yang dinyatakannya. Hal ini berarti bahwa fenomenologi memandang manusia sebagai bertujuan, mengarahkan energi psikis dan pengalamannya untuk membentuk dunia yang bermakna, yang dalam terminologi Husserl dimaksud dengan aspek intensionalitas atau keterarahan. Selanjutnya, terminologi kedua dan Husserl selain intensionalitas adalah logika transendental. Dalam hal ini, Husserl menjelaskan bahwa setiap orang merupakan subjek dan pengalaman-penqalamannya sendiri. Tetapi, orang juga menyadari tentang adanya perilaku dan peryataan ekstemal. Pengalaman orang lain juga menjadi landasan intersubjektif dan menjadi basis untuk saling berbagi dalam membangun dunia nilai dan budaya (Muhajir,1998:83).

Alfred Schutz merupakan pengikut Edmund Husserl. Pada prinsipnya, fenomenologis Schutz sama ataupun identik dan terlihami oleh fenomenologis Husserl. Yang berbeda mungkin tekanannya. Fenomenologis Schutz lebih menekankan pada pentingnya "intersubjektivitas" yang dalam bahasa Husserl termasuk pada aspek logíka transendental. Hal ini tidak berarti mengabaikan aspek intensionalitas, tapi lebih pada keinginan Schutz untuk menempatkan konsep intersubjektivitas pada jantung teorinya.

Inti dari fenomenologis Schutz adalah memandang bahwa pemahaman atas tindakan, ucapan, dan interaksi merupakan prasyarat bagi eksistensi sosial siapa pun (Mulyana, 2001:62). Sementara itu, Husserl memahami fenomenologis sebagai suatu analisis deskriptif serta introspektif mengenai kedalaman dan semua bentuk kesadaran dari pengalaman-pengalaman langsung: religius, 
moral, estetis, konseptual, serta inderawi.

Dalam Campbell (1994), Schutz berpendapat bahwa kita hanya bisa mulai memahami makna tindakan kita, ketika kita melihat kembali padanya pada saat refleksi. Lalu kita dapat menyeleksi unsur-unsur pengalaman kita yang memungkinkan kita untuk melihat tindakan kita sendiri sebagai bermakna.

Schutz mencatat, sedikitnya ada tiga hal yang perlu diperhatikan dalam "intersubjekfivitas" ataupun pemahaman kebermaknaan atas tindakan, ucapan, dan interaksi kita sebagai anggota masyarakat, yakni: situasi, tipikasi, dan motif 'supaya' \& motif 'karena' (Campbell, 1994).

Dijelaskan (dalam Mulyana, 2001:62) bahwa dalam setiap situasi fenomenologis, yakni konteks ruang, waktu, dan historis yang secara unik menempatkan individu, kita memiliki dan menerapkan persediaan pengetahuan (stock of knowledge) yang terdiri dan semua fakta, kepercayaan, keinginan, prasangka dan aturan yang kita pelajari dari pengalaman pribadi dan pengetahuan siap pakai yang tersedia bagi kita di dunia yang ke dalamnya kita lahir. Schutz memandang bahwa kategori pengetahuan pertama bersifat pribadi dan unik bagi setiap individu dalam interaksi tatap-muka dengan orang lain. Sementara, kategori pengetahuan kedua adalah berbagai pengkhasan (typication) yang telah terbentuk dan dianut semua anggota suatu budaya, terdiri dari mitos, pengetahuan, budaya, dan akal sehat (common sense).

Konsep "intersubjektifitas" dalam fenomenologis Schutz merupakan konsep yang memungkinkan kita melakukan interaksi dan komunikasi. Dengan bekal karakterisitik persediaan pengetahuan yang dimiliki, kita dapat saling berbagi perspektif dengan orang lain; dapat melakukan berbagai macam hubungan dengan orang lain. Karenanya pengetahuan kita mengenai diri kita akan berubah tatkala kita masuk dan keluar dari hubungan dengan orang iain. Pendekatan fenomenologis Schutz ini menegaskan pentingnya merekonstruksi dunia kehidupan manusia "sebenamya" dalam bentuk yang mereka sendiri alami (Mulyana, 2001:63).

Hal yang penting Iainnya dari fenomenologis
Schutz adalah motif. Alfred Schulz (dalam Campbell, 1994) menyebut motif ini sebagal motif 'supaya' dan motif 'karena'. Motif tersebut terkait dengan interaksi tatap-muka, yang mana dalam interaksi dimaksud, makna rangsangan yang dicari dan ditafsirkan oleh sang aktor secara khas merujuk kepada motif aktor lainnya. Motif 'supaya' adalah motif yang merupakan tujuan yang digambarkan sebagai maksud, rencana, harapan, minat, dan sebagainya, yang diinginkan aktor, dan karena itu, berorientasikan masa depan. Sedangkan motif 'karena', merujuk kepada pengalaman masa lalu aktor dan tertanam dalam pengetahuannya yang terendapkan, dan karena itu berorientasikan masa lalu. Motif 'karena' ini lazim disebut alasan atau sebab. Selama proses interaksi tatap muka, terdapat pertukaran motif di antara para aktor yang terlibat, dan saling pengertian hanya akan tercapai bila terdapat pertukaran motif khas yang sebangun. Seorang individu baru bisa mengubah tindakannya sesuai dengan tindakan orang lain, tatkala orang lain menginterpretasi terlebih dahulu tindakannya. Hal ini menuntut individu ataupun kita untuk memastikan terlebih dahulu makna, motif, atau maksud apa yang terdapat di belakang tindakan orang lain. Proses seperti ini hanya akan dimungkinkan bila manusia memiliki dan berbagi lambang atau pesan komunikasi dalam bentuk simbol-simbol tertentu.

Sebagai catatan, pada dasarnya fenomenologi merupakan landasan filosofi dari interaksi simbolik. Interaksi simbolik mengejar makna di balik yang sensual, mencari fenomena yang esensial dari sekadar gejala (Muhajir, 2000). Sebagaimana lazimnya, studi interpretif (fenomenologi) ini bersifat ideografis, yakni menemukan pola-pola, tema-tema, model-model, atau proposisi-proposisi yang sesuai dengan kasus yang diteliti. Jadi, analisisnya bersifat induktif(Mulyana, 2001).

\section{Metode dan Prosedur Penelitian}

Penelitian ini dilakukan dengan mewawancarai secara mendalam 10 informan dari mahasiswi berjilbab dan mengamati perilaku dari mahasiswi 
berjilbab di kampus Universitas Islam Bandung selama tiga minggu. Hal ini terkait dengan motivasi mahasiswi memakai jilbab sebagai identitas seorang muslimah. Kesepuluh informan mahasiswi berjilbab ini, memakai jilbab dengan gaya dan bentuk yang bervariatif.

Pada wawancara mendalam, peneliti berupaya mengambil peran pihak yang diteliti (taking the role of the othegar), secara intim menyelam ke dalam dunia psikologis dan sosial mereka. Agar mencapai tujuannya, pewawancara harus mendorong pihak yang diwawancarai dengan berbagai cara untuk mengemukakan semua gagasan dan perasaannya dengan bebas dan nyaman. Pendek kata, situasi wawancara lebih mirip situasi percakapan yang ditandai dengan spontanitas (Mulyana, 2001:183).

Pendekatan penelitian dalam studi ini adalah pendekatan kualitatif. Menurut Nawawi Martini (1994:174), penelitian kualitatif atau naturalistik adalah penelitian yang memiliki karakteristik, penelitian yang datanya dinyatakan dalam keadaan yang sewajarnya atau sebagaimana adanya (natural setting), sedang yang menjadi objek penelitian kualitatif adalah seluruh bidang atau aspek kehidupan manusia, yakni manusia dengan segala sesuatu yang dipengaruhi manusia.

Salah satu perspektif yang digunakan dalam penelitian kualitatif adalah perspektif fenomenologi. Penggunaan perspektif fenomenologi ini dimaksudkan untuk merekonstruksi kehidupan manusia ke dalam bentuk yang mereka alami sendiri. Pendekatan fenomenologi menuntut bersatunya subjek peneliti dengan subjek pendukung objek penelitian. Keterlibatan subjek peneliti di lapangan mengahayatinya menjadi salah satu ciri utama penelitian dengan pendekatan fenomenologi (Muhadjir, 1992 : 28-29)

Selanjutnya, dari Garna (1999: 32), pendekatan kualitatif dicirikan oleh tujuan penelitian yang berupaya untuk memahami gejala-gejala yang sedemikian rupa tidak memerlukan kuantifikasi, atau karena gejala tersebut tidak memungkinkan diukur secara tepat. Sedangkan Moleong (2004:6) mengatakan bahwa penelitian kualitatif adalah penelitian yang bermaksud memahami fenomena tentang apa yang dialami subjek penelitian, misalnya perilaku, persepsi, motivasi, tindakan, dan lain-lain secara holistik yang dideskripsikan pada konteks khusus yang alamiah dan memanfaatkan berbagai metode ilmiah. Mulyana (2001:147) mengistilahkan penelitian kualitatif dengan 'PerspektifSubjektif'. Tujuan dari penelitian dalam perspektif subjektif adalah:

Menangani hal-hal yang bersifat khusus, bukan hanya perilaku terbuka, tetapi juga proses yang tak terucapkan, dengan sampel kecil/purposif, memahami peristiwa yang mempunyai makna historis, menekankan perbedaan individu, mengembangkan hipotesis (teori) yang terikat oleh konteks dan waktu, membuat penilaian etis/estetis atas fenomena (komunikasi ) spesifik.

Interpretasi terhadap perilaku subjek penelitian dilakukan dengan mengetahui apa yang ada di benak seseorang mencakup perasaan, motif, dan pemikiran yang ada di balik perilaku seseorang, yang diperoleh berdasarkan wawancara mendalam sehingga memungkinkan peneliti memahami subjek penelitian dalam situasi ilmiah secara menyeluruh.

\section{Analisis Konstruksi Sosial Mahasiswa Berjilbab}

Berdasarkan pengamatan, mayoritas mahasiswi di Unisba memakai jilbab. Jilbab yang peneliti temukan tidaklah seragam. Bentuk, corak, dan ukurannya bermacam-macam. Ada yang terlihat trendi, dengan jilbab yang ujungnya dililit ke belakang, atau hanya diikat di dagu (yang terkadang ketika angin berhembus menyibak sebagian jilbabnya yang memperlihatkan lekuk lehernya), kaos lengan pendek dipadu dengan manset panjang dengan warna senada, sehingga dapat menutup seluruh lengan, juga celana jeans yang ketat. Dapat ditemukan juga mahasiswi yang mengenakan jilbab yang menjuntai hingga sebatas pundak, yang ujungnya dibiarkan menutupi bagian depan dadanya, ia memadukannya dengan blus dan corak yang kontras dengan warna jilbabnya. Dan terakhir mahasiswi dengan jilbab sampai sikusiku bahkan lebih, dengan baju gamis atau (terusan 
panjang) atau dengan baju kurung. Kelompok terakhir inilah yang fenomenal.

\subsection{Kategori Kelompok Mahasiswa Berjilbab}

Uniknya, peneliti lihat bentuk yang bermacam ini juga memperlihatkan perbedaan perilaku di antara mahasiswi yang menggunakan jilbab. Dari sini, penulis membuat suatu kategori berdasarkan corak busana dan jilbab yang dikenakan oleh mahasisiwi Universitas Islam Bandung, menjadi tiga kelompok:

\subsubsection{Kelompok Mahasiswi Berjilbab "Lebar"}

Di Universitas Islam Bandung, mahasiswi pemakai jilbab lebar kerap disebut jilbaber. Dari pengamatan penulis terhadap mahasiswi yang menggunakan jilbab lebar, penulis melihat ada berbagai macam pula segi bentuk dan modelnya mahasiswi yang memakai jilbab lebar ini. Ada mahasiswi yang hanya mengenakan gamis, baju kurung dengan rok, yang semua serba lebar dan panjang dengan warna gelap, misalnya hitam, biru tua, coklat, dan lain-lain, tanpa corak dan model yang bervariasi. Namun, ada pula yang memakai jilbab lebar yang berani untuk membuat variasi dalam model jilbab dan kerudungnya, sehingga tampak lebih modis dengan warna yang lebih bervariasi. Hal ini juga dibenarkan oleh Ummu Anis, salah satu informan yang berjilbab lebar. Menurutnya, periode pertama jilbaber memang penampilannya cenderung monoton. Dan, pada periode selanjutnya berubah dan lebih terbuka. Menurutnya, ini adalah suatu perkembangan yang menggembirakan. Karena jilbab lebar, menurut masyarakat sampai saat ini, tergolong eksklusif, dan untuk beradaptasi dan lebih terlihat inklusif, maka lapisan kedua dari generasi ini memilih warnawarna cerah, tanpa keluar dari jalur-jalur syar'i yang telah digariskan.

\subsubsection{Kelompok Mahasiswi Berjilbab "Gaul"}

Mahasiswi kelompok ini, dilihat dari penampilan mereka, tampak sekali bahwa mereka sangat mengikuti perkembangan mode. Menurut peneliti, penampilan mereka tidak ada bedanya dengan penampilan mahasiswi modis yang tak berjilbab yang penulis temui di Universitas Islam Bandung tersebut, kecuali seikat kain yang melilit di kepala mereka. Wajah mereka segar dipoles dengan make up, ada yang tampak natural, ada juga yang agak berlebihan, seperti lipstik yang menyala, juga parfum harum yang menggoda orang yang melewatinya untuk menghirupnya.

Pakaian yang mereka kenakan beragam. Umumnya memakai celana ketat, dengan kaos panjang, atau kaos pendek yang disambung dengan manset, atau blouse yang memperlihatkan lekuk pinggang. Ditemukan juga mahasiswi dari kelompok ini, yang memakai rok panjang, dengan kaos ketat membungkus badan. Bahkan penulis pernah menemukan beberapa mahasiswi, mengenakan rok dengan belahan di belakang sampai batas lutut. Suatu pemandangan yang tidak umum di Universitas Islam Bandung.

Berdasarkan pengamatan tampaknya gaya jilbab inilah yang mendominasi mahasiswi di Universitas Islam Bandung.

\subsubsection{Kelompok Mahasiswi Berjilbab "Semi"}

Dari pengamatan peneliti di kampus Universitas Islam Bandung, sebenarnya banyak mahasiswi yang berpenampilan tidak terlalu ketat, juga tidak terlalu lebar. Mereka memakai rok, atau celana kulot (celana yang tidak terlalu ketat), baju atasan yang juga longgar sampai ke lutut, dengan jilbab menjulur hingga pundak atau sedikit lebih. Yang sebenarnya bisa dikategorikan sebagai kelompok ketiga. Karena mereka memang berbeda dengan kelompok pertama dan kedua. Busana yang mereka kenakan sulit untuk dikatakan jilbab gaul, maupun jilbab lebar.

Umumnya mereka memakai rok, atau celana kulot (celana yang tidak terlalu ketat) baju atasan yang juga longgar sampai ke lutut, dengan jilbab menjulur hingga pundak atau sedikit lebih. Selain jilbab, pola pikir dan interaksi mereka tidak jauh berbeda dengan yang berjilbab gaul. Hanya kelihatan lebih beretika.

Dari wawancara yang peneliti lakukan terhadap 10 informan mahasiswi berjilbab terdiri 
dari mahasiswi berjilbab gaul, mahasiswi berjilbab lebar, dan mahasiswi yang berjilbab semi, masingmasing mewakili kelompoknya tersebut, pandangan mereka tentang jilbab beragam.

Ridhki F. dari Fakultas Psikologi Unisba, salah seorang informan mahasiswi dengan jilbab sedang (semi), mengatakan bahwa jilbab ideal menurutnya adalah yang tidak terlalu lebar juga tidak terlalu kecil. Sejak masuk Unisba sampai sekarang, ia memakai jilbab dengan ukuran sedang (semi). Sebenarnya dia ingin memakai jilbab lebar, dan menutupi auratnya sebagaimana mestinya, tapi belum mampu. Karena ia takut konsekuensi yang akan ditanggungnya, jika berubah penampilan. Bahkan ia mengaku pernah mencoba memakai jilbab panjang dan gamis beberapa hari, namun teman-teman mereka mengolok-olok "ada akhwat baru".

"Kalau saya berpenampilan seperti itu terus, takutnya orang mengira saya sudah alim, dan saya rasa itu berat, apalagi kalau saya sendiri tidak bertanggung jawab secara moral, itu kan bisa merusak citra para jilbaber," menurut Ridhki.

Demikian juga dengan Aimee dan Sari, baginya jilbab yang ideal yang dikatakan oleh Ridhki. Mereka menyadari gaya jilbab yang dikenakan menabrak kaidah-kaidah berpakaian syari'ah. Hal itu disebabkan lingkungan di mana ia berinteraksi sebagian besar anggotanya berjilbab gaul, dan lingkungan keluarga melarangnya untuk memakai jilbab lebar.

Mereka juga mengaku berpacaran, dan terkadang tidak memakai jilbab di depan teman lakilaki mereka, ketika di rumah atau di tempat kosan mereka. Dari sini juga dapat dikonklusikan bahwa sebagian mahasiswi memakai jilbab bukan implementasi terhadap firman Allah, tapi lingkungan tempat ia berinteraksilah yang mempengaruhi pada gaya jilbab penampilan mereka.

Sedangkan Tuesty, salah satu mahasiswi dari kelompok ini, adalah model yang unik. Pribadinya, gaya bicaranya, berbeda dengan informaninforman lain yang berjilbab gaul. Menurut peneliti, ia cerdas dan punya sikap. Menurutnya, ia berpenampilan gaul, karena ingin menampilkan sosok muslimah yang tidak old fashioned, dan menunjukkan bahwa muslimah bisa juga bergaya tanpa harus meninggalkan atribut keislaman.

Dari beberapa informan mahasiswi ini setidaknya diperoleh kesimpulan, bahwa sebagian besar mereka yang berjilbab "gaul' masih gamang dalam penampilan. Bahkan ada yang mengaku bahwa ia menabrak kaidah-kaidah syari'ah yang telah ditetapkan, dengan alasan lingkungan tempat ia berinteraksi tidak berpenampilan yang ia yakini.

Fenomena jilbab gaul jelas tampak muncul di negara kita sekitar pasca reformasi di tahun 1998. Tahun 1998 adalah awal gebyar era euforia perayaan kebebasan. Tidak hanya dalam bidang politik, di mana partai-partai tumbuh subur. Tapi juga suburnya media massa dengan berbagai corak dan segmennya, turut memengaruhi gaya hidup masyarakat, khususnya remaja.

Berbeda halnya dengan pandangan mahasiswi berjilbab lebar. Nenden, aktivis Lembaga Dakwah Kampus Unisba, salah satu informan dari mahasiswi berjilbab lebar, menurutnya jilbab berfungsi untuk menutup aurat. Jilbab adalah seluruhnya dari kepala hingga kaki. Itulah jilbab yang perintahnya datang dari Allah yang mengandung kebaikan. Jilbab lebar adalah jilbab yang sesuai dengan syar'i agama. Jilbab adalah pakaian seperti lorong tidak terpotong-potong, tidak membentuk, tidak transparan, tidak ketat. Dengan kata lain, seorang muslimah ketika keluar harus memakai gamis longgar dengan kerudung lebar. Seseorang yang memakai baju atas ketat dan kerudung, syarat menutup aurat telah dipenuhinya, tapi dia belum memakai jilbab.

Menurut Kefgen dan Touchie-Specht, busana mempunyai tiga fungsi: (1) differensiasi, (2) perilaku, dan (3) emosi. Dengan busana, orang membedakan dirinya, kelompoknya, atau golongannya dan orang lain.

Rakhmat menyatakan bahwa busana muslimah mendorong pemakainya berperilaku yang sesuai dengan citra diri muslimah. Busana muslimah mendefinisikan peran dengan tegas. Ia mernbantunya dalam role playing dan menghindari role confusion. L. Langner menulis bahwa:

"Dengan memakai pakaian seragam kelompok 
tertentu, seseorang menunjukkan — melalui pakaian seragamnya itu-bahwa ia telah melepaskan haknya untuk bertindak bebas sebagai seorang individu dan (sebaliknya) mesti bertindak sesuai dengan dan dalam batas-batas kaidah kelompoknya".

ABRI yang berpakaian seragam akan merasakan perilakunya berbeda ketika ia menggunakan pakaian preman. Santri yang menanggalkan sarung dan peci serta menggantinya dengan blue-jeans dan T-shirt akan merasakan perubahan perilaku (Rakhmat, 2004: 140-141).

Jika dihubungkan antara pernyataan Rakhmat dan pernyataan informan di atas, tampaknya tidak semua busana muslimah mendorong pemakainya untuk berperilaku yang sesuai dengan citra diri muslimah. Telah terjadi pemetaan perilaku pemakai jilbab gaul, jilbab sedang (semi), dengan pemakai jibab lebar.

Realitas jilbab "gaul” ini menyebabkan, terjadinya pergeseran makna jilbab. Jilbab tidak melulu dikaitkan dengan kesalehan individu seperti dulu, mengingat perilaku perempuan yang berjilbab tidak berbeda dengan yang tak berjilbab, bahkan tidak menutup kemungkinan perilaku mereka yang tak berjilbab lebih “islami” dari pada mereka yang berjilbab. Tapi, tetap saja, jilbab adalah pernyataan dari pemakainya, bahwa ia seorang muslimah. Namun di tangan mereka juga, jilbab dapat merambah ke semua kalangan. Jilbab tidak lagi ditakuti, juga tidak terlihat kampungan dan eksklusif. Bahkan jilbab telah menjadi medan interpretasi yang penuh makna.

Di Universitas Islam Bandung, para pemakai jilbab lebar mempunyai wadah dalam melakukan aktivitasnya sebagai sarana pembinaan diri dan lingkungan yang biasa dalam lembaga dakwah kampus. Lembaga tersebut dikenal dengan Lembaga Dakwah Kampus(LDK). Lembaga inilah yang banyak mengadakan aktivitas-aktivitas keagamaan dan pendidikan dengan tujuan mengembalikan dan menerapkan nilai-nilai Islam secara kaffah.

\subsection{Motif Berjilbab}

Melihat realitas jilbab di kalangan mahasiswi Universiats Islam Bandung, berhubungan dengan gaya jilbab yang dikenakannya dan perilaku yang mengenakannya, peneliti mengategori motif yang bisa dipakai saat melihat alasan memakai jilbab yaitu jilbab dengan motif teologis, jilbab dengan motif psikologis, dan jilbab dengan motif modis.

\subsubsection{Jilbab dengan Motif Teologis}

Jilbab dengan motif teologis, menunjukkan bahwa memakai jilbab atas alasan kewajiban agama. Mahasiswi yang mengenakan jilbab ini akan memahaminya sebagai kewajiban yang tidak bisa ditinggalkan. Bentuk jilbab pun sesuai dengan standar-standar syariat, tak hanya menutup rambut dan kepala, tapi juga menurut sebagian dari mereka-hingga sampai ke dada. Jilbab yang lebar, bila perlu menutupi seluruh tubuh. Mahasiswi yang mengenakan jilbab seperti ini juga akan berhatihati bergaul di ruang publik.

Pada kategori "jilbab dengan motif teologis" ditemukan pada setiap pernyataan yang hampir sama dari mahasiswi (informan) yang memakai jilbab lebar.

"Saya memakai jilbab lebar sejak bergabung di Lembaga Dakwah Kampus Unisba. Sebelumnya, saya memakai jilbab sedang. Yang memotivasi saya untuk berjilbab adalah untuk menjalankan perintah Allah Swt dalam QS Al-Ahzab:59. Saya memakai jilbab yang seperti ini -- lebar, selain menjalankan syariat, juga karena jilbab ini membuat saya mudah untuk menjalankan ibadah shalat, tanpa harus membawa mukena." (Ummu Anis, Fakultas Tarbiyah Unisba).

"Saya memakai jilbab sejak Tsanawiyah di Pesantren Diniyah Putri Padang Panjang. Yang memotivasi saya untuk berjilbab lebar jelas pengejawantahan dari firman Allah SWT QS AlAhzab:59. Selain itu, keluarga saya adalah aktivisaktivis dakwah yang sudah tidak asing lagi dengan jilbab lebar." (Ratna Desi, Fakultas Syariah Unisba)

"Saya memakai jilbab sejak awal masuk SMA PGII Bandung. Pakai jilbab lebar ketika saya aktif di lembaga dakwah kampus. Motivasi saya berjilbab lebar karena dalam agama Islam sangat ditekankan aturannya untuk wanita harus memakai jilbab, tidak boleh tidak, dan menutup semuanya kecuali muka dan telapak tangan" ( Rina Pratiwi, Fakultas Syariah Unisba). 


\subsubsection{Jilbab dengan Motif Psikologis}

Jilbab dengan motif psikologis adalah jilbab karena alasan kenyamanan psikologis. Mahasiswi yang berjilbab atas motif ini sudah tidak memandang lagi jilbab sebagai kewajiban agama, tapi sebagai budaya dan kebiasaan yang bila ditinggalkan akan membuat suasana hati tidak tenang. Bentuk jilbab yang dikenakan berbeda dengan model pertama, dan disesuaikan dengan konteks dan fungsinya. Demikian juga dengan gaya hidup yang memakainya, jauh lebih terbuka, dan pergaulan mereka sangat luas, berbeda dengan model pertama.

"Saya memakai jilbab sejak kelas 3 SMU. Motivasi berjilbab untuk melindungi diri dari gangguan lawan jenis. Saya merasa nyaman dengan jilbab semi yang saya pakai, lebih praktis tidak terlalu ribet seperti jilbab lebar. Saya memakai jilbab di mana dan kapan saja kecuali di rumah." (Devi Oktaviani, Fakultas Ekonomi, Unisba)

"Saya memakai jilbab sejak tahun 2006, setelah seminggu lebaran. Motivasinya, ingin menjalankan perinta agama, ingin berubah menjadi yang lebih baik yang salah satu caranya memakai jilbab. Saya memakai jilbab 'semi' karena belum berani memakai jilbab yang lebar. Saya memakai jilbab ketika di luar rumah, dan tidak memakainya ketika di dalam rumah.” (Ridhki, Fakultas Ilmu Komunikasi, Unisba)

"Saya memakai jilbab sejak semester pertama. Motivasi saya karena kewajiban seorang muslim untuk menutup auratnya, di mana memakai jilbab merasa lebih terjaga kehormatannya dan terlindungi. Saya merasa nyaman dengan jilbab yang saya kenakan, gak ribet. Saya memakai jilbab setiap ke luar rumah, ketika di dalam rumah tidak pakai jilbab.” (Aprianti, Fakutas Psikologi, Unisba).

\subsubsection{Jilbab dengan Motif Modis}

Jilbab dengan motif modis, jilbab sebagai produk fashion. Tampak pada mahasiswi yang mengenakan jilbab lebih karena alasan gaya. Bagi sebagian orang, mengenakan jilbab memberi keuntungan-keuntungan secara fisik, misalnya, untuk menutupi kekurangan tubuh atau sekedar menarik respek dari orang lain. Ada pula yang mengenakan jilbab tanpa alasan yang spesifik, lebih karena "pengen aja", "kayaknya enak", dan sebagainya. Peneliti memandang jilbab model ini sebagai jawaban terhadap tantangan dunia model yang sangat akrab dengan perempuan. Namun, di sisi lain, ada nilai-nilai agama yang berusaha dipertahankan dan sebagai merek dagang. Tidak dapat dipungkiri, jilbab modis sangat menjamur, sangat digemari kawula muda. Mengenakan pakaian ketat, namun tetap setia berjilbab. Jilbab dengan motif modis tidak bisa lagi dilihat melalui model pertama teologis.

"Saya memakai jilbab sejak semester dua. Awalnya, saya memakai jilbab gaul karena pengen seperti sobat saya yang kelihatan tetap trendy setelah pakai jilbab. Apalagi jilbab sekarang modelnya ga kampungan, jadi saya masih tetap bisa gaya meski pakai jilbab. Karena saya kuliah di Fikom, di mana nantinya saya ingin kerja di stasiun tv. Kayaknya, enak jika pake jilbab gaul. Ga tau ya nanti bisa berubah. Karena saya juga masih dalam proses." (Nenden, Fakultas Ilmu Komunikasi, Unisba)

"Saya memakai jilbab ketika masuk Unisba yang berlabelkan Islam. Sebelum saya pakai jilbab, pakaian saya sehari-hari, kata orang, modis. Mungkin saya memang begitu. Saya lebih memilih pakai jilbab gaul hanya ingin mengubah image seorang muslimah yang notabene old fashion, menjadi muslimah yang fashioned tanpa harus meninggalkan atribut keislamannya." (Tuesty Septianti, Fakultas Psikologi Unisba)

"Saya memakai jilbab sejak SMA. Saya memilih pakai jilbab gaul karena pengen aja biar tetap trendy dan tidak ketinggalan zaman. Lagian saya khan masih muda, masih enjoy dengan gaya jilbab seperti ini." (Aimee, Fakultas Teknik Unisba).

"Saya memakai jilbab sejak 2006, saya memilih pakai jilbab gaul karena ikut trend mode jilbab sekarang yang lucu-lucu. Apalagi banyak artis-artis kita sekarang yang pakai jilbab, tapi tetap cantik dengan mode jilbab yang mereka kenakan. Saya suka ikutin gaya berjilbab Inneke. Saya belum kepikiran untuk berjilbab lebar." (Sari, Fakultas Ilmu Komunikasi, Unisba) 


\subsection{Identitas Mahasiswai Berjilbab}

Sebagai suatu rangkaian proses, identitas mahasiswi berjilbab didasarkan pada motif dan perilaku mereka dalam memaknai dan memahami jilbab sebagai simbol keislaman. Peneliti mengategorikan identitas mahasiswi berjilbab yakni Mahasiswi Muslimah Fenomenal, Mahasiswi Muslimah Fashionable, dan Mahasiswi Muslimah Toleran.

\subsubsection{Mahasiswi Muslimah Fenomenal}

Mahasiswi dengan identitas Muslimah Fenomenal adalah informan yang memakai jilbab lebar. Simbol keshalehan. Para jilbaber (demikian mereka biasa disebut) banyak ditemukan di Masjid Al-Asy'ari Unisba. Bahkan, mereka dijuluki sebagai penguasa masjid, terutama bagi mahasiswa dan mahasiswi yang aktif di Lembaga Dakwah Kampus ini (LDK). Hal itu karena sekretariat LDK Unisba menempati lantai bawah masjid tersebut.

Ukhuwwah - demikian mereka mengistilahkan persaudaraan mereka - sangat kuat sekali. Hal itu terlihat sekali ketika dua orang mahasiswi berjilbab lebar bertemu, apalagi jika keduanya satu organisasi. Dari jauh mereka akan saling melempar senyum yang lebar, dan bersalaman erat sekali dengan menggerakkan ujung-ujung jari masingmasing ke atas, sambil mengucapkan salam, cium pipi kanan kiri dan berpelukan erat, seakan-akan mereka sudah lama tidak bertemu.

Para pemakai jilbab "lebar" cenderung tidak banyak bicara, tertawa terbahak-bahak, atau jarang sekali ditemukan para pemakai jilbab "lebar" duduk (nongkrong) di teras-teras kampus, atau bersamasama dengan laki-laki untuk bersamaan, atau bahkan untuk diskusi-diskusi di taman dengan teman-teman lain. Yang menarik lagi, peneliti mengamati bahasa yang mereka gunakan cenderung kearab-araban. Mereka memanggil temannya yang memakai jilbab "lebar" juga dengan panggilan akhwat atau $u k h t i$, dan untuk laki-laki yang mempunyai aktivitas yang sama dengan ikhwan atau akhat.

Adanya fenomena di atas, menyebabkan para pemakai jilbab "lebar" dikenal tertutup dan cenderung berkelompok. Kecenderungan para pemakai jilbab "lebar" untuk berkelompok, disebabkan kekhawatiran para pemakai jilbab lebar terwarnai oleh lingkungan yang kurang baik. Sehingga, mereka lebih memilih bergaul dengan orang-orang yang memakai jilbab "lebar" lagi dengan alasan supaya keimanan yang mereka bina dan jaga selama ini tidak luntur.

\subsubsection{Mahasiswi Muslimah Fashionable}

Mahasiswi dengan identitas Muslimah Fashionable adalah informan yang memakai jilbab gaul. Simbol modernisasi. Mereka sangat mengikuti perkembangan mode. Pergaulan mereka tampak lebih "cair" dibanding mereka yang berjilbab dengan niat hijrah dari busana jahiliah ke busana yang islami. Dalam artian, cara bergaul mereka tidak merepresentasikan jilbab yang mereka pakai, seperti akhlak yang buruk, pacaran dan lain-lain. Meski berlabel Islam, di kampus ini dapat dijumpai pula mahasiswa dan mahasiswi duduk berduaan, pacaran. Mahasiswi yang berpacaran adalah mahasiswi berjilbab "gaul".

Diakui oleh Tuesty, salah seorang informan mahasiswi berjilbab gaul, bahwa kehidupan seharihari mahasiswi kelompoknya ini cenderung individualis, suka-suka gue, emang gue pikirin. Menurut Tuesty, hal yang merekatkan mereka adalah perkembangan fashion, musik, gosip, curhat tentang pacar. Namun yang terakhir ini, bisa juga menjadi sumber konflik.

\section{Model Proses Mahasiswi Memilih Gaya Jilbab} Sebagai Identitas Muslimah

$\begin{array}{lll}\text { Alasan } & \text { Motif } & \text { Kategori } \\ \begin{array}{l}\text { Identitas } \\ \text { Kewajiban agama }\end{array} & \text { Teologis } & \text { Jilbab "lebar" } \\ \begin{array}{l}\text { Muslimah Fenomenal } \\ \text { Kenyamanan }\end{array} & \text { Psikologis } & \text { Jilbab "semi" } \\ \begin{array}{l}\text { Muslimah Toleran } \\ \text { Trend mode, gaya }\end{array} & \text { Modis } & \text { Jilbab "gaul" } \\ \begin{array}{l}\text { Muslimah Fashionable } \\ \end{array}\end{array}$




\subsubsection{Mahasiswi Muslimah Toleran}

Mahasiswi dengan identitas Muslimah Toleran adalah informan yang memakai jilbab semi (sedang). Kelompok ini berada di antara mahasiswi berjilbab lebar dan berjilbab gaul. Mereka tidak mengambil jarak untuk berinteraksi dengan mahasiswi berjilbab lebar atau berjilbab gaul. Berdasarkan pengamatan, meskipun jilbab, pola pikir, dan interaksi mereka tidak jauh berbeda dengan yang berjilbab gaul. Mereka kelihatan lebih beretika.

Adapun Model Kontruksi Sosial Jilbab sebagai simbol keislaman dan identitas muslimah mahasiswi berjilbab Universitas Islam Bandung dapat dituangkan dalam model sebagaimana tampak pada gambar 1.

\section{Kesimpulan}

Konsep jilbab didasarkan pada kewajiban agama Islam bagi pemeluknya untuk menutup aurat dengan jilbab, terutama kaum muslimah. Seperti terlihat dalam analisis, pada prakteknya, tidak semua perempuan muslim mempunyai pemahaman dan kesadaran yang sama mengenai konsep jilbab tersebut. Dalam konteks ini, jilbab menjadi medan interpretasi yang penuh makna.

Motivasi mahasiswi berjilbab memakai gaya jilbab yang variatif terdiri dari gaya jilbab "lebar", jilbab "gaul”, dan jilbab "semi" dapat dilihat dari alasan-alasan yang mendorong mereka untuk berjilbab dengan gaya berbeda. Berbagai alasan tersebut dibuat dalam tiga kategori motif, yaitu motif teologis yang menunjukkan berjilbab atas alasan kewajiban agama, motif psikologis yang menunjukkan berjilbab atas alasan kenyamanan, dan motif modis yang menunjukkan berjilbab atas alasan trend mode atau sekadar gaya.

Sebagai suatu rangkaian proses, identitas mahasiswi berjilbab didasarkan pada motif dan perilaku mereka dalam memaknai dan memahami jilbab sebagai simbol keislaman yakni Mahasiswi

Gambar 1

Model Proses Mahasiswa Memilih Gaya Jilbab sebagai Identitas Muslimah

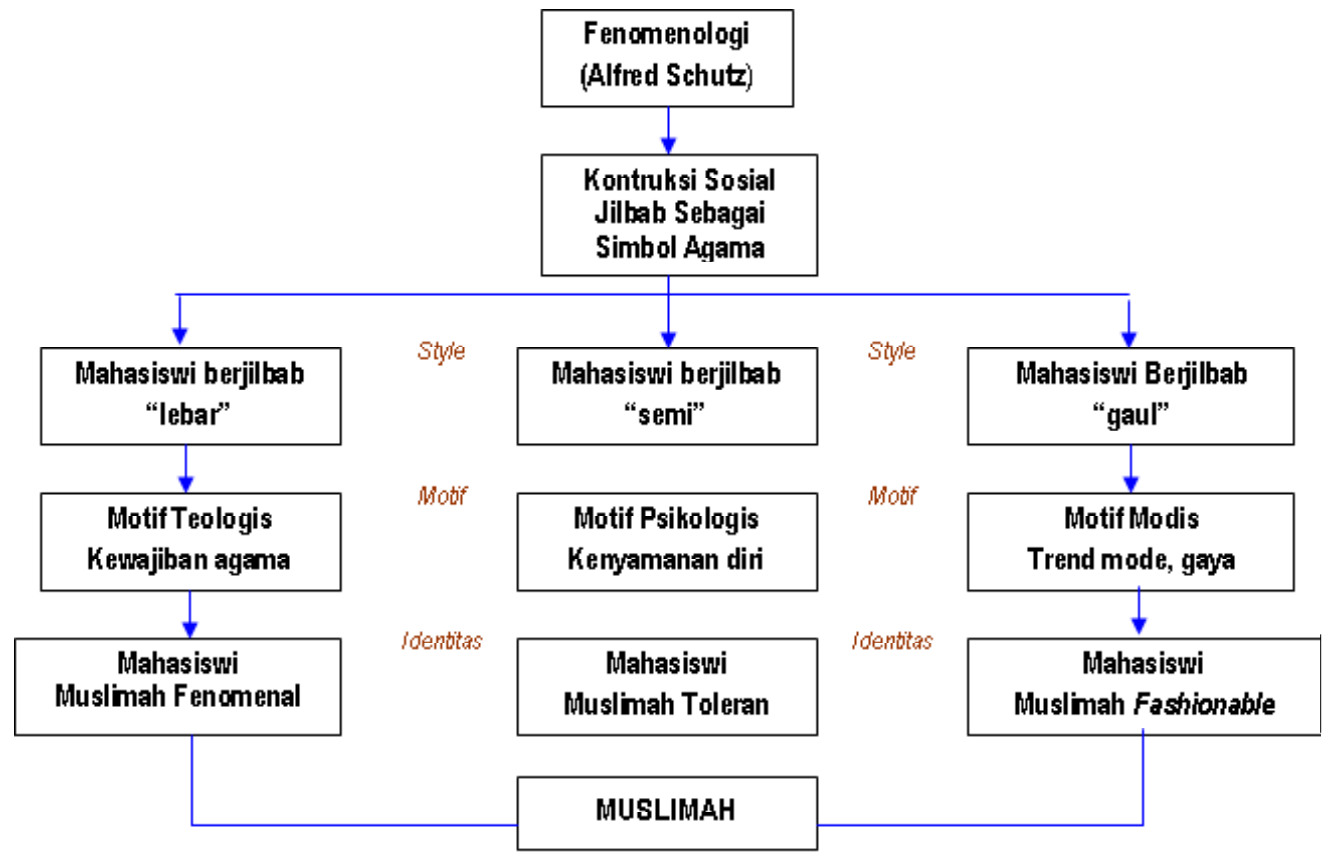

Dadi Ahmadi dan Nova Yohana. Konstruksi Jilbab sebagai Simbol Keislaman. 
Muslimah Fenomenal, Mahasiswi Muslimah Fashionable, dan Mahasiswi Muslimah Toleran yang menunjukkan karakteristik yang khas dari identitas mahasiswi berjilbab Universitas Islam Bandung.

Kepribadian tidak dapat diukur dengan pakaian, akan tetapi cara berpakaian seseorang akan mencerminkan kepribadian seseorang. Melalui pakaian, dandanan, dan tingkah laku pada tiap-tiap masa menyiratkan sebuah pernyataan yang sangat kuat tentang kelas, status, dan gender. Perspektif fenomenologis, menganggap kesadaran manusia dan makna subjektivitasnya sebagai fokus untuk memahami tindakan sosial.

\section{Daftar Pustaka}

Al-Ghifari, Abu. 2004. Berjilbab tapi Telanjang. Bandung: Mujahid Press.

Campbell, Tom.1994. Tujuh Teori Sosial, Yogyakarta: Kanisius.

Chaplin, Cp. 1981. Dictionary of Psychology. Terjemahan, New York: Dell Publ.

Geertz, Clifford. 1992. Kebudayaan dan Agama, Penerjemah Francisco Budi Hardiman. Yogyakarta: Kanisius.

Gerungan. 1996. Psikologi Sosial. Bandung: Eresco.

Kartono, Kartini. 1993. Kamus Lengkap Psikologi, Cetakan Kedua. Jakarta: Raja Grafindo Persada.

Liliweri, Alo. 1994. Komunikasi Verbal dan Non Verbal. Bandung: Citra Aditya Bakti.

Moleong, J. Lexi. 2004. Metodologi Penelitian Kualitatif. Bandung: Remaja Rosdakarya.

Muhadjir, Noeng. 1996. Metodologi Penelitian kualitatif. Edisi II. Yogyakarta. Penerbit Rake sarasin.
Mulyana, Deddy. 2000. Ilmu Komunikasi Suatu Pengantar. Bandung: Remaja Rosdakarya.

. 2001. Metodologi Penelitian Kualitatif. Bandung: Remaja Rosdakarya.

Purwanto, Ngalim. 1985. Psikologi Pendidikan. Bandung: Remadja Karya.

Rais, M. Amin. 1991. Prospek Proses Kebangunan Islam. Bandung: Mizan.

Rakhmat, Jalaluddin. 2004. Islam Alternatif. Bandung: Mizan.

1999.Psikologi Komunikasi. Bandung: Remaja Rosdakarya

Rakhmat, Jalaluddin. 1999. "Kritik Paradigma Pasca Positivisme terhadap Positivisme," Jurnal ISKI Vol.3 / April, Bandung Remaja Rosda Karya.

Sobur, Alex. 2003. Semiotika Komunikasi. Bandung: Remaja Rosdakarya.

Suryabrata. Sumadi. 1993. Psikologi Pendidikan. Jakarta: Raja Grafindo Persada.

Surtiretna, Nina, et. al. 2003. Anggun Berjilbab. Bandung: AL-Bayan.

Turner, Bryans. 2003. Agama dan Teori Sosial. Yogyakarta : IRCISOD

\section{Sumber Lain:}

Maulani Achmad. 2006. Jilbab Antara Kesalehan, Kesopanan dan Perlawanan, Retrieved, Juli 17, 2007 from www.Islamlib.com

Hestirahayu. 2007. Jilbab antara Gaya dan Rekonstruksi, Retrieved, Juli 16, 2007 from: http://hestirahayu.blogspot.com 